\title{
Spatial distribution patterns of metals in the bottom sediments of artificial reservoirs in south Sardinia, Italy
}

\author{
Fadda S. ${ }^{\prime}$, Fiori M. ${ }^{\prime}$, Matzuzzi C. ${ }^{l}$, and ${ }^{*}$ Grillo S. M. ${ }^{2}$ \\ 'Istituto di Geologia Ambientale e Geoingegneria del CNR, Cagliari, Italy \\ ${ }^{2}$ Dipartimento di Geoingegneria e Tecnologie Ambientali, Università di Cagliari \\ (*Email: grillo@unica.it)
}

\begin{abstract}
The Flumendosa-Campidano system of artificial lakes is the major water resource for southern Sardinia, Italy. The main basins of this system are situated in ore-rich terrains which are responsible for the supply of different heavy metals in the bottom sediments forming in these lakes. The chemical and mineralogical composition of these materials reflects the lithology of the country rocks and is strongly influenced by the surrounding ore mineral occurrences. Because of the semiarid climate of this island, along with the uneven distributions of rains and increasing water demand, water levels in these lakes are prone to broad yearly variations and consequently their sediments are periodically prone to the action of the meteoric waters and of the atmosphere which causes oxidation and remobilisation of most metals. However the metal-rich sediments of the lakes appear at present sufficiently stable as elemental concentrations in the water reaching the treatment plants are normally below the permissible limits for drinking water. Metals re-precipitate in less soluble forms and accumulate in the deepest parts of the sedimentary piles which would act as a trap for the metals. Data on metal contents in the sediments are examined in view of deriving pollution risks. Distribution maps have been drawn for each element for assessing its dispersion and accumulation effects. The mapping together with statistical treatment of the results and comparison with previous data has shed light on the origin and distribution of the various pollutants.
\end{abstract}

\section{INTRODUCTION}

The most part of the Southern Sardinia is supplied by the Flumendosa-Campidano hydraulic system, which has been built and managed by the Ente Autonomo Flumendosa (EAF) since the mid 1950's. This reservoir system includes six interconnected artificial lakes of different sizes (Fig. 1). Lake Flumendosa is the most important water collector of the system. It receives waters from an extensive drainage area and from two minor lakes, Alto Flumendosa and Flumineddu. Lake Mulargia has a less important drainage basin; the main function of this lake is to store excess water, conveyed through a tunnel, from Lake Flumendosa. In addition, small basins downstream ensure the water resources to the distribution network located mainly in the Campidano plain. The water collected by the system comes from the upper and middle reaches of the River Rio Flumendosa, which crosses the central part of the island and includes the southern part of the Gennargentu massif, the highest mountain range in Sardinia. For about 30 years, this system is being used as the main water supply for all kinds of consumption, including civil, agricultural and industrial uses, to the most densely populated zone of Sardinia, an Italian island at the centre of the western Mediterranean.

The overall volume of the system amounts to about $6.2 \times 10^{8} \mathrm{~m}^{3}$ (Istituto dell'Ambiente 1992) and the yearly average total volume distributed to the users is $225 \mathrm{Mm}^{3}$ with $90 \mathrm{Mm}^{3}$ for drinking purpose and $15 \mathrm{Mm}^{3}$ for industrial purpose. Agricultural use $\left(120 \mathrm{Mm}^{3}\right)$ takes the major share (about $60 \%$ ) not only because of the real necessities in a warm and semiarid climate, but also its waste owing to lacking consumption controls. In addition heavy pipeline losses negatively affect the supply balance.

The lake levels are strongly influenced by the climate characterised by two short rainy periods (late autumn and early spring) and a long dry season (from late spring to early autumn), at least six months of warm, dry weather during which lake levels drop, most of the water is consumed and extensive bottom areas gradually emerge all along the lake borders and sediments dry out (Fadda et al. 1998). With the rains, the lakes slowly fill up again attaining the maximum possible level and remain full for a short time span. In the past decades recurrent droughts have heavily affected the reserves of the system. As a consequence, water levels in these lakes are prone to wide variations and accordingly the lake bottom sediments are subjected to cyclic exposure, reworking by the incipient river flows after the first heavy rains, possibly followed by a new supply of detrital material.

The drainage basins of these reservoirs mostly include Palaeozoic terrains hosting polymetallic ( $\mathrm{Pb}, \mathrm{Zn}, \mathrm{Cu}, \mathrm{Fe}, \mathrm{As})$ sulphide mineralisations (Fig. 2). Several of these bodies have been explored and some of them have been mined, so that mining excavations, trenches, galleries, and exploitations gave origin to numerous dumps which, along with the unexplored mineralised outcrops, supply heavy metals to the lake sediments. In addition the rocks surrounding the 


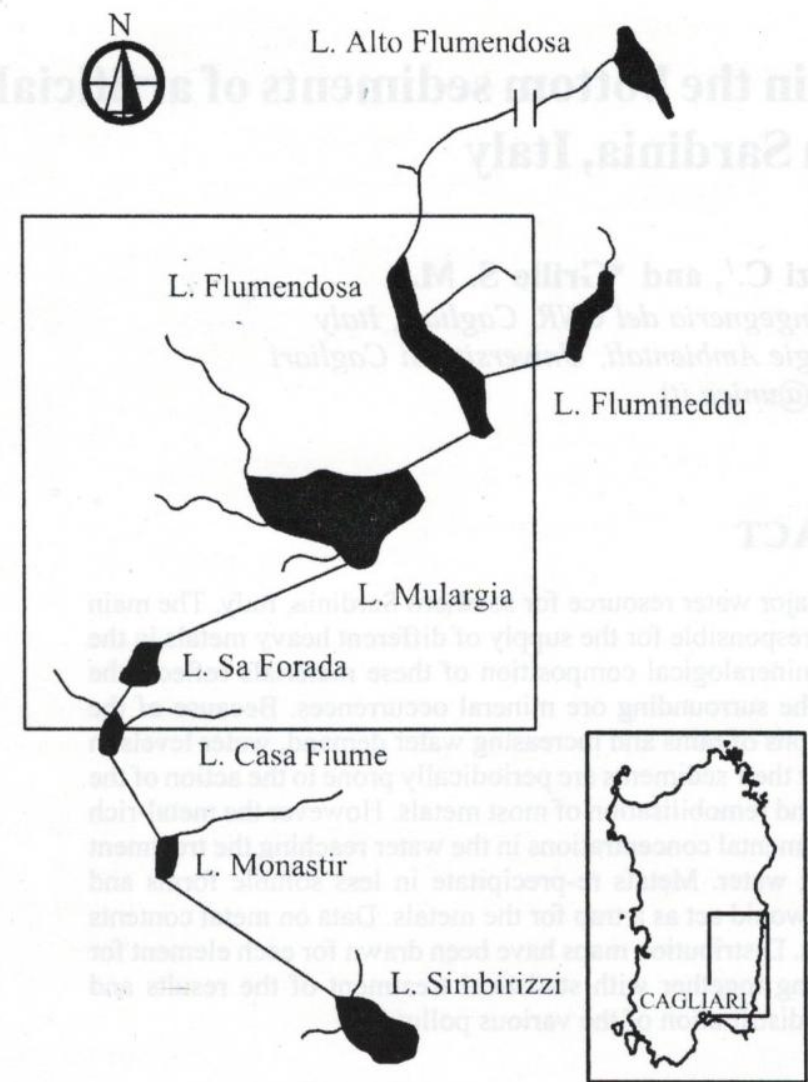

Fig. 1: Sketch map of the Flumendosa-Campidano reservoir system lakes show the content of metals quite high as compared with the average world contents for the corresponding rock facies. In recent years the fluxes of many trace elements from terrestrial or atmospheric sources to the aquatic environment of these reservoirs have increased either as a direct action of mining and other industrial operations or as an indirect consequence owing to acid drainage resulting in an increase in the weathering products. As a result of complex physical, chemical, and biological processes a major fraction of these metals is found associated with the sediments of these lakes. This supply is both clastic (mostly sulphides) and in solution, due to the acidic environment in the surrounding outcrops. Acidic waters originate from sulphide minerals that at most mining sites are gradually accumulated and exposed in waste-rock piles and tailings impoundments. The oxidation of pyrites seems to be the primary source of acid generation that influences the aqueous geochemistry of stream systems. The investigation of acid mine drainage (AMD) in these locations aims to predict effluent qualities, quantities, and the lifecycle of acidic waters from the wastes. At many locations mining has been active for several decades. Although the period of most intense sulphide oxidation and associated release of dissolved metals has passed away, the transport of contaminants through underlying aquifers will continue. The clastic sulphide fraction deposited in proximal sediments is in turn prone to oxidation during the dry season; the smallest grains are totally destroyed and the largest ones are dramatically reduced in size and the following flood carries away the rest of sulphide grains along with metal ions.

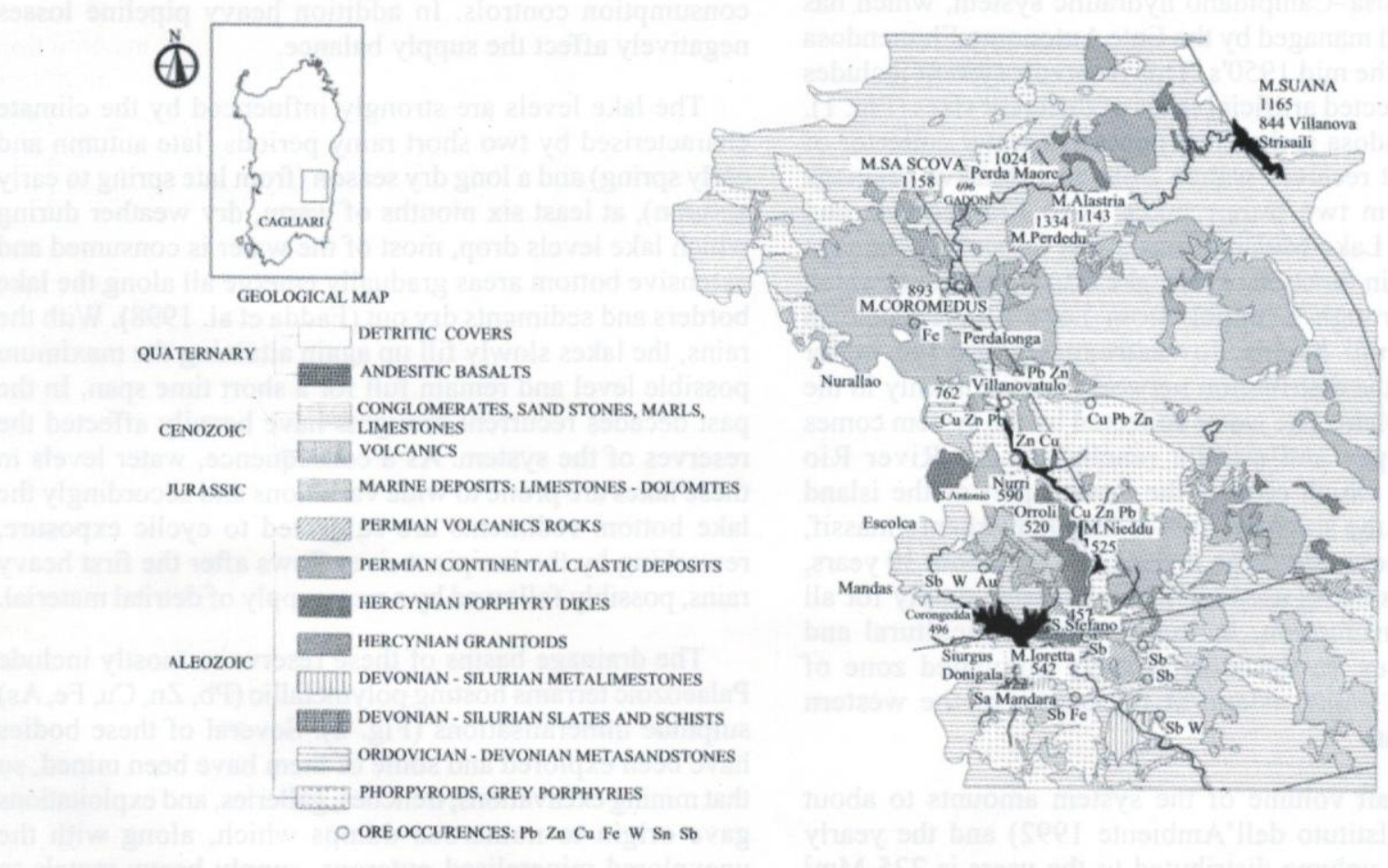

Fig. 2: Geological sketch map of terrains surrounding the main lakes of the Flumendosa-Campidano system 
The cyclic exposure of the reservoir sediments and the possible presence of base metal-bearing minerals in these sediments were investigated by soil sampling, analysis, and statistical treatment of the analytical results. A significant number of sediment samples were collected and several elements were analysed. The data collected reflect the influence of several sources: elements in the sediments may be found as constituents of primary rock-forming minerals, as mineral formed during weathering, as minerals typical of mineralisations, as ions adsorbed onto colloidal particles and clays, and in combination with organic matter. The mapping programme of the lakes has used the metal concentrations of the fine fractions of the sediments. Analytical results were treated using statistical methods and the populations defined. For each element, distribution maps were drawn by means of computer-assisted cartography in order to visualise the inlets of the contaminants and dispersion and accumulation effects.

Several anomalous zones were discovered and the sources of the geochemical signals were identified by considering the multi-element relationships and the spatial structures of the data. As regards the source of the metals, they originate mostly from the Palaeozoic crystalline basement, where high geochemical backgrounds for several metals as well as mineralised concentrations exist. There is also contribution from Quaternary basalts. The location of the main anomalous areas of the studied metals well fits with the known geological characteristics of the terrains as well as the areas of anthropogenic activity. Metals come in the reservoirs from dispersed sources, including ore occurrences, ore mineral disseminations and, more generally, from highbackground effects and from concentrated sources by the wastewater discharge of mine works, which however appear to represent the main feeders. This study aims at identifying the mineralogical phases and different rock types hosting the geochemical signals in order to isolate the influence of the various sources. It also aims at characterising the factors controlling the spatial structure, dispersion, and variability of the data. These properties are inherent to the geochemical landscape and may provide information on the extent of geochemical sources and dispersion processes forming haloes of metal concentrations in the secondary environment.

\section{DRAINAGE BASINS GEOLOGY AND ORE OCCURRENCES}

\section{Lake Flumendosa reservoir}

The Flumendosa reservoir, which crosses the central part of Sardinia, has a sharply elongated form, with a length of about $17 \mathrm{~km}$ and a maximum width of about $500 \mathrm{~m}$, reflecting the canyon morphology of the Flumendosa valley. This lake has an average depth of $35 \mathrm{~m}$ and its maximum capacity is $316 \mathrm{Mm}^{3}$.

It is the most important water collector of the system and receives water from an extensive drainage area and from two minor reservoirs by means of an artificial tunnel. In addition to a few main tributaries, several brooks and small streams cut the steep flanks of the valley along the entire length of the lake draining several rock complexes of different ages and lithologies (Fig. 2). These complexes include a Palaeozoic crystalline bedrock covered by Mesozoic and Tertiary marine sediments as well as by Quaternary basalts. Palaeozoic terrains comprise terrigenous sequences, with interbedded carbonate lenses and calc-alkaline acidic volcanics ("porphyroids") intruded by Hercynian granites (Carmignani et al. 1982). All sedimentary and volcanic sequences underwent folding and regional metamorphism as well as thermal metamorphism induced by granite intrusions with the formation of shales, micaschists, gneisses, marbles, hornfelses, and skarns. Permian terrains locally cover this metamorphic complex (Marcello 1961). The Mesozoic series includes basal conglomerates, clays, and a thick carbonate complex. At the southern borders of the basin, Eocene conglomerates and limestones occur discontinuously, followed by a continuous cover of Miocene sandstones, marls, and limestones. Ore mineral occurrences in Palaeozoic terrains include skarn-related mixed-sulphides and magnetite occurrences, sulphide disseminations in "porphyroids", and quartz veins containing variable amounts of sulphides and barite. Minor concentrations of pyrite, with traces of other sulphides, occur irregularly in the Mesozoic clays associated with plant remnants. Sulphide minerals include base metal sulphides and minor sulphosalts; magnetite-rich ores also include variable amounts of sulphides, as well as minor quantities of haematite. Small amounts of tin and tungsten minerals also occur in skarn-related mineralisations.

Active erosion in the drainage basin favours an abundant accumulation of sediments in the lake. Some $2.35 \mathrm{Mm}^{3}$ of sediments deposited at the bottom of this lake in about thirty years (Bazzoffi 1993). When, at the beginning of the autumn rains, the first water flows cut the bottom sediments emerged during the dry season, these sediments display a thickness of several metres at the thalweg. Materials accumulated include a major mineral fraction (from coarse gravel to silt and clay), a minor organic fraction (including plant and animal debris), as well as an extremely various set of human products. Rythmic granulometric variations indicate cyclic water flow intensity variations, also related to seasonal migration of the "shoreline" as well as with varying water depth.

The numerous ore bodies occurring upstream as well as those surrounding the lake are considered prime sources of heavy metals scattered in these sediments. An extensive mining and exploration has affected not only important ore bodies but also a number of minor occurrences and almost all the mineralised outcrops known in this area. Among the upstream occurrences the $\mathrm{Cu}-\mathrm{Zn}-\mathrm{Pb}$ mine of Funtana Raminosa operated on several important mixed sulphide lenses practically from Bronze Age up to a few years ago. The mining activity has left behind outcrop- and underground-excavation dumps and dressing plant tailings. Not far from this ancient mine, a less important group of sulphide lenses has been recently exploited for a few years. 
A group of million-ton-size magnetite lenses has been actively explored, though not exploited, in the vicinity of this mine. Upstream and downstream swarms of sulphide lenses of variable sizes have been explored and discontinuously exploited.

Among the occurrences surrounding the Flumendosa reservoir, a group of $\mathrm{Cu}-\mathrm{Zn}$ - $\mathrm{Pb}$-bearing bodies, mostly outcropping on the left flank of the main valley, were actively exploited by a small mining enterprise during the first half of the last century. A few excavations, with their dumps, are situated below the maximum level of the present lake, and are prone to emersion-immersion cycles. Several minor ore bodies occur in lateral valleys.

\section{Lake Mulargia reservoir}

The reservoir of Lake Mulargia was completed in 1963. It has a maximum capacity of about $350 \mathrm{Mm}^{3}$ and a roughly triangular shape with a maximum surface area of about 124 $\mathrm{km}^{2}$. The area around the lake includes a Palaeozoic crystalline basement overlain by younger sediments and volcanic rocks (Fig. 2). The lower to middle Palaeozoic basement (Carmignani et al. 1982) comprises predominantly clastic metasediments, mostly shales and metasandstones with marble lenses, and acidic metavolcanic "porphyroids". These are covered by lacustrine sediments of Permian age, mainly conglomerates to siltstones, overlain by porphyritic rocks. The series crops out along the northern and eastern sides of the lake (Marcello 1961). On the northern side rests the transgressive Jurassic series, including a quartzose conglomerate passing to sandstone and clay and finally to carbonate beds. Again on the northern flank of the lake, there is a new continental phase, represented by Eocene conglomerates. The Miocene transgression is represented by platform limestones and marls (western side), while the last continental phase (Pliocene to Recent) is represented by alluvium (northern side) and flood basalts (eastern side).

The terrains in the drainage basin include complexes hosting heavy-metal bearing mineralisations, mostly basemetal sulphides accompanied by hydrothermal alteration. These sulphides may be the principal arsenic-bearing minerals in the source rocks. Within the Palaeozoic rocks, the most important supply source is the disused Genna Ureu mine, where $\mathrm{Fe}, \mathrm{As}, \mathrm{Sb}$, and $\mathrm{W}$ minerals occur with minor $\mathrm{Cu}$, $\mathrm{Au}, \mathrm{Ag}, \mathrm{Bi}, \mathrm{Ni}$, and Co contents. This mine and the surrounding metavolcanic rocks are situated in the Rio Mulargia drainage basin, which enters the lake at the western corner. Other small manifestations consist of pyrite lenses and disseminations, occurring all around the lake's perimeter, in particular in the Rio Norizzi basin, with a drainage area of about $15 \mathrm{~km}^{2}$ and drained by minor tributaries flowing into the southern corner of the lake. Besides the mine pits, trenches, galleries, small mining explorations, unexplored mineralised outcrops and numerous mine waste dumps, and other anthropogenic factors come into play. For example, Lake Mulargia receives water from Lake Flumendosa through a tunnel situated in the northeastern part (Fig. 1).

\section{Lake Sa Forada}

The natural drainage basin of Lake Sa Forada covers an area of a few square kilometres, delimited by a roughly semicircular watershed culminating in the hills of S. Miali, Coronas Arrubias, and Sa Perrima. This small artificial lake receives water from the Flumendosa-Mulargia reservoirs and supplies first to a power plant, then to the Campidano plain, mostly for agricultural purposes. The volume of water draining into the lake is extremely modest, but carries with it material coming from the intensely mineralised area, currently under exploitation, of the Furtei mine, a typical example of a volcanic-hosted high-sulphide epithermal gold deposit. Mining commenced in 1997 for confirmed reserves totalling 2150000 metric tonnes containing $2.82 \mathrm{~g} / \mathrm{t} \mathrm{Au}$. Consequently the elements contained therein may have some influence on the characteristics of the water discharged from this intermediate reservoir. The area is characterised by a volcano-sedimentary sequence of Oligo-Miocene age, overlying marine and fluvio-lacustrine sediments of late Eocene - early Miocene age, which in turn rest on a Palaeozoic basement, composed of metasediments, metapelites, and quartzites. The outcropping volcanosedimentary sequence consists of andesitic sub-volcanic domes and pyroclastic products such as fall, surge, and ash-flow deposits. These outcrops are locally and partially overlain by Miocene and Quaternary fluvio-lacustrine and marine sediments. Most of the volcano-sedimentary complex in the area has undergone hydrothermal alteration and mineralisation. Four types of alteration have been recognised: propylitisation, argillisation, strong argillisation, and silicification. Hydrothermal alteration was overprinted by supergene, secondary argillisation, mainly after oxidation of the sulphide phases. Pyritisation is widespread in all types of alterations with major concentrations occurring in the innermost areas of intense alteration, where it practically grades into the ore bodies. The main mineralised bodies, already explored and mined in their upper oxidised portion are Santu Miali, Is Concas, and Sa Perrima groups. The paragenetic study revealed the following typical highsulphide assemblages respectively in an order of their abundance: pyrite, enargite-luzonite, tetrahedrite, tennantite, chalcopyrite, covellite, digenite, galena, sphalerite, arsenopyrite, wurzite, tellurides, native $\mathrm{Au}$, and native $\mathrm{Te}$ (Fiori et al. 2001). Near the outcrops, deep oxidation related with the abundant pyrite transforms these bodies into an assemblage of Fe-hydroxides, quartz, sulphates (gypsum, jarosite, barite) with minor arsenates and other secondary minerals. Gold easily survives as a native element, and remnants of sulphides and sulphosalts are also commonly present.

\section{SAMPLING AND ANALYSIS}

\section{Sampling pattern and procedure}

The narrow and extremely elongated shape of Lake Flumendosa together with the hydrological pattern of the Flumendosa valley determined the sampling pattern based 


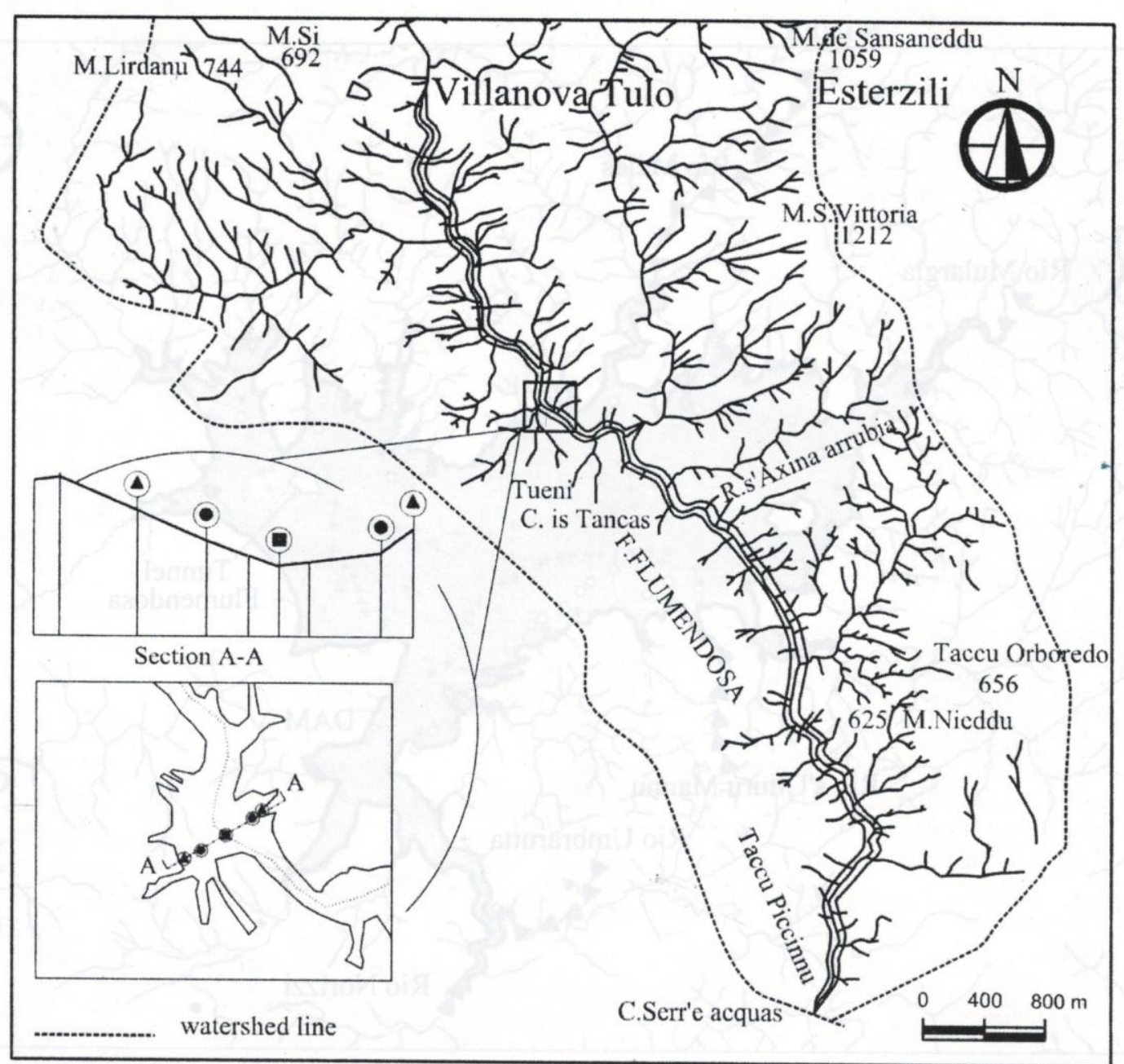

Fig. 3: Sketch map of Lake Flumendosa showing the drainage patterns and, in an ideal section normal to elongation the two "near-shore" sampling sites (triangles), two "mid-lake" sites (circles), and one "lake-bottom" site (square).

on three sample lines, one along the lake shore at its maximum, another along the main river thalweg, and an intermediate line. In an ideal section normal to elongation, the sampling sites considered are two "near-shore" sites, two on both sides, two "mid-lake" sites, and one "lake-bottom" site (Fig. 3). These ideal sections were positioned slightly downstream from the tributaries in order to perceive the influence of their supply. In the main tributary valleys, whose lower courses are actually part of the lake and are covered by lake sediments, thalweg samples were collected; the number of sampling sites in each valley depended on the valley size, and more precisely on the valley tract occupied by the lake. In each site one or more samples were collected, depending on the sediment thickness and exposure. Single samples were collected from all "near-shore" sites with thin sediments, rather resembling stream sediments. Single samples were also collected from most "mid-lake" and tributary valley sites. Almost all "lake-bottom" sites, a few "mid-lake" sites, and sites near the outlets of the main tributaries are characterised by thick, well bedded deposits. Time for sample collection in these sites was opportunely chosen during the recent severe droughts as well as maintenance works on the dam, when the lake was almost empty, in a period of still abundant water flow; natural sediment sections cut by these flows were easily sampled in all their exposed levels. Sampling was incomplete in the lake tract near the dam which never became empty; few "lake-bottom" samples were dredged. A total of 176 samples of $0.5 \mathrm{~kg}$-size were collected from the whole lake.

The sample collection in Lake Mulargia was carried out in 1990 from its deepest part, and in 1991 from the marginal parts. The submerged drainage framework was reconstructed on the basis of old maps allowing for the samples to be collected following the streams entering the lake (Fig. 4). In the central part of the lake bottom, along the old Rio Mulargia bed and locally along a few important tributaries, the thick sequences of sediments, cut by the most recent water flows, were sampled as stratigraphic columns, while laterally, on 


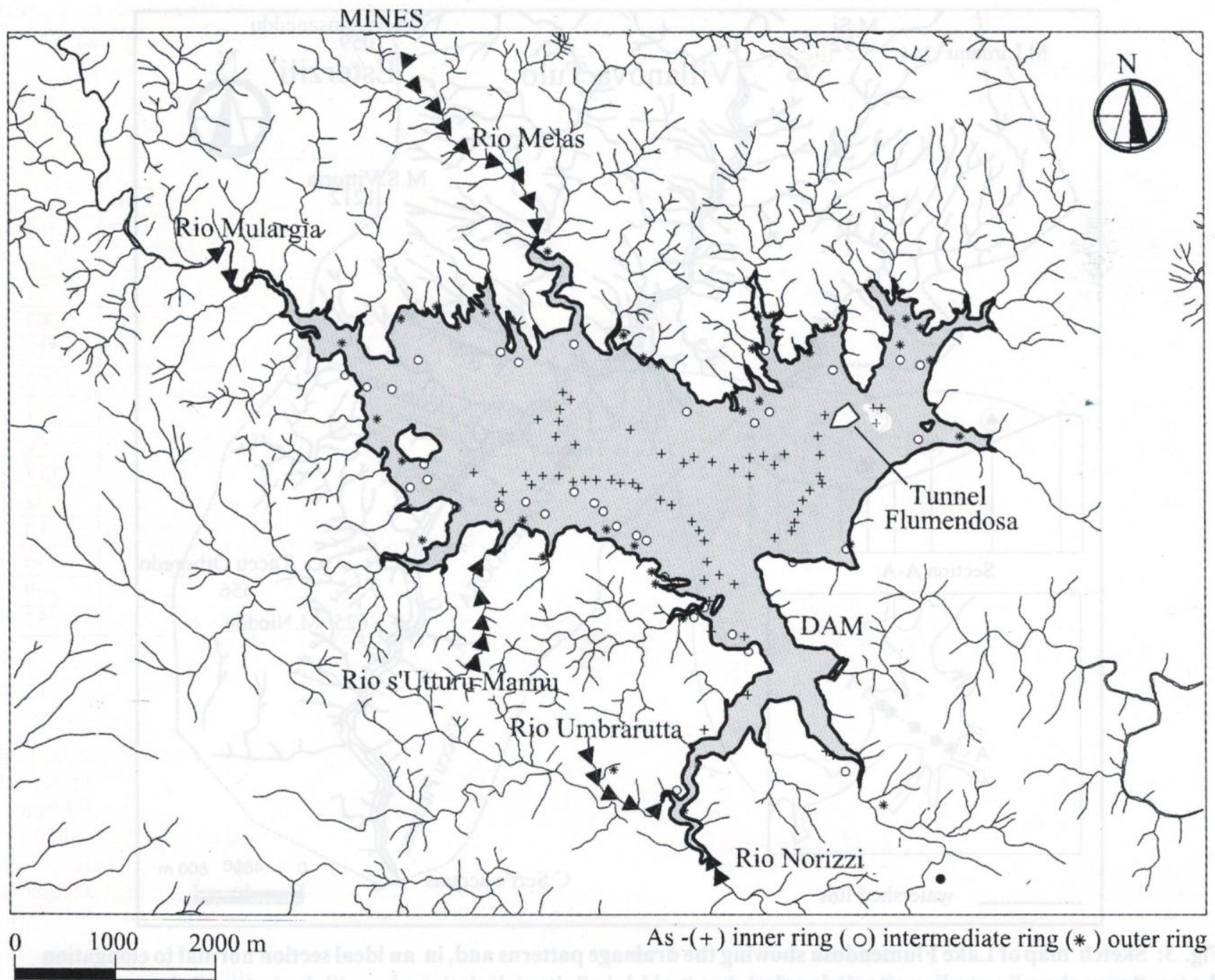

Fig. 4: Sketch map of lake Mulargia showing the sampling pattern with the three rings of samples collected: Crosses: "bottom" samples (first or inner ring); circles: "mid-lake" samples (second or intermediate ring); asterisks: "nearshore" samples (third or outer ring). Dots represent the sampling sites in the rocks surrounding the lake. Some important tributaries (with triangles), Flumendosa tunnel outlet, and the position of the dam are also shown.

leaving the axial zone of the bottom, the total sediment thickness, which never exceeds $20 \mathrm{~cm}$, was collected as a simple sample. Inter-stream (pure "lacustrine") sediments were also collected; normally they do not exceed $5 \mathrm{~cm}$ in thickness. Following this scheme, three "rings" were sampled in the central bottom area, in the intermediate zone, and along the border of the lake at its maximum level for a total of 140 sampling sites and more than 200 samples of $0.3 \mathrm{~kg}$-size were collected. To verify the influence of the surrounding terrains further sampling was carried out in the main rock facies around the lake.

The bottom sediments of Lake Sa Forada were sampled when it was emptied for dam maintenance. The samples were collected following the pre-existing hydrographic pattern, both along the thalweg lines and in the inter-thalweg surfaces
(Fig. 5). The sediment thickness ranged from a few centimetres near the shoreline to a few metres near the dam. Given the small size of the lake, 44 samples, averaging about $300 \mathrm{~g}$ in weight, were collected. In addition to the lake sediments, samples of rock were also taken from the main rock facies around the lake in order to ascertain the influence of the surrounding terrains.

\section{Sample preparation and analysis}

After a low-temperature drying, each sample was carefully disintegrated and split into two batches, one of which was stored for further controls wherever necessary. The remaining second half was split again, and a quarter was sieved to $<2 \mathrm{~mm}$ and the finer fraction was taken for analyses. The above mesh size was chosen in accordance with the earlier studies conducted by the European 


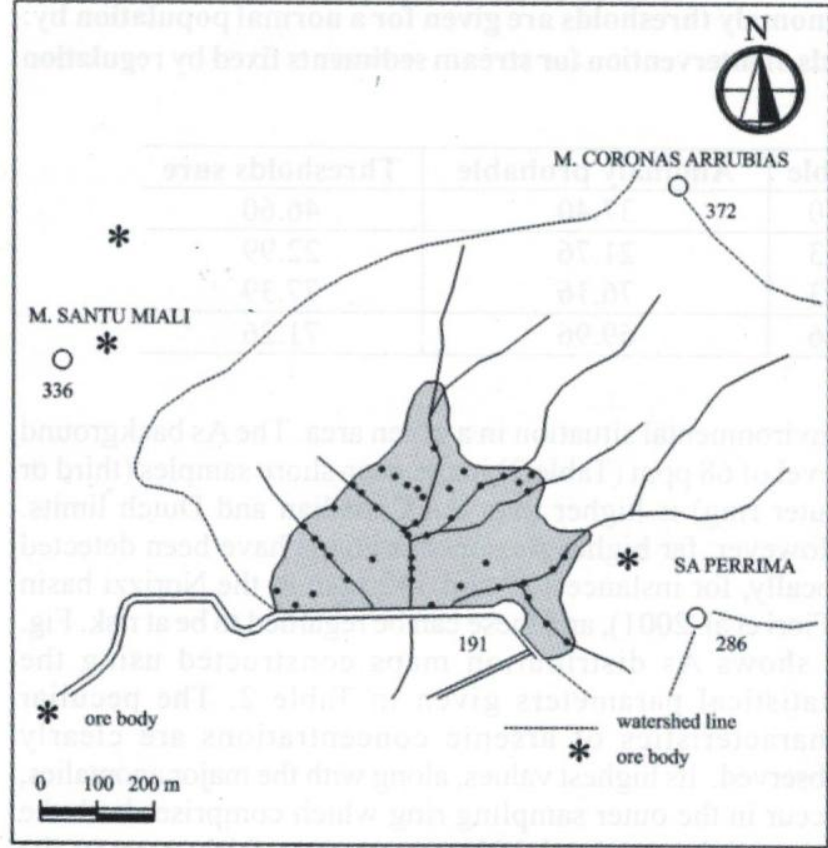

Fig. 5: Schematic map of Sa Forada area with the drainage pattern, sampling sites, and the ore bodies of Furtei mine

Community Commission (ECC) Institute of the Environment to enable a comparison of results and for the sake of consistency with previous studies on lake sediments in Sardinia. Grain size analysis was done on the other half of most samples. The elements chosen for the analyses are those known or presumed to be present in the surrounding rocks and discovered ore bodies and carried into the lake sediments as clasts or soluble and (or) leaching substances.

After mixed acid leaching of $0.2 \mathrm{~g}$ fractions performed in a fully automatic microwave oven, the obtained solutions, diluted to $100 \mathrm{ml}$, were analysed through Atomic Absorption Spectrometry (AAS), Direct Current Plasma-Atomic Emission Spectrometry (DCP-AES), and Inductively Coupled PlasmaMass Spectrometry (ICP-MS). An aqua regia-based extraction was used for Au leaching from sub-samples of $5 \mathrm{~g}$. For $\mathrm{Hg}$ analyses, sub-samples of $2 \mathrm{~g}$ were treated in reflux heating with a mixture of $\mathrm{H}_{2} \mathrm{SO}_{4}$ and $\mathrm{HNO}_{3}$. The hydride generation system was used for the subsequent AAS determinations. The validation of the analytical procedures was assessed on accuracy tests using the standard reference materials SARM-7 and MA-2 for gold and sediments GSD-9 to 12 for the other elements.

\section{RESULTS AND DISCUSSION}

Resulting statistics for a set of 16 heavy metals analysed in the 176 sediment samples from Lake Flumendosa (Table 1) show that they generally exhibit the same distributions as expected in their primary occurrences; those from ore bodies form log-normal populations with the only exception of $\mathrm{Sb}$,
Table 1: Main statistical parameters of considered elements in Lake Flumendosa. Asterisk: log-normally distributed element. Values in ppm.

\begin{tabular}{r|r|r|r|r|r}
\hline Element & Mean & $\begin{array}{r}\text { St. dev./ } \\
\text { Var. coeff. }\end{array}$ & Min & Max & Range \\
\hline $\mathrm{Ag}^{*}$ & 3 & 13.49 & 0 & 102 & 102 \\
\hline $\mathrm{As}$ & 62 & 17 & 15 & 107 & 92 \\
\hline $\mathrm{Ba}$ & 1.05 & 2.75 & 4 & 4.3 & 0.3 \\
\hline $\mathrm{Bi}$ & 2 & 16.60 & 0 & 360 & 360 \\
\hline $\mathrm{Cd}$ & 3 & 43.65 & 0 & 71 & 71 \\
\hline $\mathrm{Co}$ & 43 & 24 & 13 & 220 & 207 \\
\hline $\mathrm{Cr}$ & 139 & 47 & 44 & 290 & 246 \\
\hline $\mathrm{Cu} *$ & 195 & 2.75 & 10 & 1872 & 1862 \\
\hline $\mathrm{Hg} *$ & 0.03 & 218 & 0 & 31 & 31 \\
\hline $\mathrm{Mo}$ & 1 & 15.49 & 0 & 46 & 46 \\
\hline $\mathrm{Ni}$ & 60 & 20 & 21 & 138 & 117 \\
\hline $\mathrm{Pb}^{*}$ & 251 & 3.31 & 0 & 2.02 & 2.02 \\
\hline $\mathrm{Sb}$ & 3 & 2 & 0 & 10 & 10 \\
\hline $\mathrm{Sn}^{*}$ & 15 & 2.57 & 1 & 141 & 140 \\
\hline $\mathrm{W}^{*}$ & 56 & 2.40 & 8 & 708 & 700 \\
\hline $\mathrm{Zn}^{*}$ & 692 & 2.40 & 27 & 4494 & 4467 \\
\hline & & & & & \\
\hline
\end{tabular}

and those associated with rock facies (basalts) show normal distributions. Arsenic and barium are only apparent exceptions; actually, soluble Ba mainly comes from feldspars, which are abundant in hydrothermal albitisations, and As is mainly associated with pyrite disseminations in "porphyroids" where this sulphide is a kind of accessory mineral.

The striking aspect is that some elements occur in concentrations often elevated, and a few speciation trials (Pinna 2000) showed that significant fractions of these metals occur in soluble forms capable to pollute the water, at least occasionally, if solution formation is possible. In the middle of the Lake Flumendosa, thick sediments emerged during a recent exceptional lowering of the water level due to maintenance works at the dam (Fadda et al. 1998). At that time, ongoing sulphide oxidation was observed, but, when the metal-enriched water squeezed from the sediments reached the higher- $\mathrm{pH}$ (about 8) water of the river flowing in its old bed, Fe-hydroxides immediately precipitated. It was also noticed that the water level variations of the lake were marked on the rocky walls by thin carbonate coatings suggesting that buffering of the acid solutions produced by sulphide oxidation, by the high-pH river water, induced both adsorption of heavy metals on the newly formed Fehydroxide (Stumm and Morgan 1970) and re-precipitation of the surviving metallic ions as carbonates. Similar phenomena also occur in the thinner border sediments, prone each year to oxidation conditions not only in Lake Flumendosa but also in Lake Mulargia whose water, coming mostly from Lake Flumendosa, also has a high $\mathrm{pH}$. The sulphide grains 
Table 2: Main statistical parameters for As in Lake Mulargia. Anomaly thresholds are given for a normal population by: means plus 1,2, and 3 standard deviations (Arsenic limit thresholds of intervention for stream sediments fixed by regulation of Canada: 33, and Holland: 55). Values in ppm.

\begin{tabular}{l|l|c|c|c|c}
\hline \multicolumn{1}{c|}{ Element } & Mean & Standard deviation & Possible & Anomaly probable & Thresholds sure \\
\hline As-inner & 19.00 & 9.20 & 28.20 & 37.40 & 46.60 \\
\hline As-intermediate & 19.30 & 1.23 & 20.53 & 21.76 & 22.99 \\
As-outer & 73.70 & 1.23 & 74.93 & 76.16 & 77.39 \\
\hline As-population & 67.36 & 1.30 & 68.66 & 69.96 & 71.26 \\
\hline
\end{tabular}

deposited in proximal sediments undergo oxidation during the dry season; the smallest grains are totally destroyed and the largest ones are dramatically reduced in size; the following floods carries away the rest of sulphide grains along with metal ions, which in turn are re-precipitated as carbonates or adsorbed on Fe-hydroxides in the inner part of the lake. In this way, mobile metals $(\mathrm{Zn})$ as well as $\mathrm{Pb}, \mathrm{Cu}$, $\mathrm{As}, \mathrm{Cd}$, and others appear to behave in the same manner, settle mostly in the inner sediments. The metals originate mostly from the Palaeozoic crystalline basement, where both a high geochemical background for several metals ( $\mathrm{Cd}, \mathrm{As}$, $\mathrm{W}$, and other less important ones) and mineralised concentrations exist. Quaternary basalts also contribute elements such as $\mathrm{Cr}, \mathrm{Ni}$, and $\mathrm{Co}$ often associated with mafic rocks.

The chemical analysis results of 200 sediment samples collected from Lake Mulargia were statistically treated to detect the existence of any homogeneous population and then determine its statistical parameters (Table 2). The geological sources of arsenic can be traced to the rock formations of the drainage basin which have a high natural geochemical background of heavy metals and where Asbearing ores occur, thus producing sites with a considerable contamination potential. Samples of the Palaeozoic rocks cropping out around the lake yielded an arithmetic mean of about $250 \mathrm{ppm}$ for As which is just indicative and overestimated as it is affected by the ore mineral disseminations occurring quite near the lake shore. The highest As values along with the major anomalies were in fact observed near the shore and appeared to be related to sulphide occurrences in the vicinity of the lake. The high values observed near the stream inlets in the northwestern corner (Rio Mulargia, Rio Melas) are related with research and mining explorations about $1 \mathrm{~km}$ upstream in the W-Sb-As-Au bearing ore body of the disused Genna Ureu mine. Arsenic values as high as $100 \mathrm{ppm}$ have been detected in the southern corner of the lake at the inlet of the Rio Norizzi where the Rio Umbrarutta and Rio S' Utturu Mannu also drain into the lake (Fiori et al. 2001). In Italy there is no legislation regulating metal concentrations in stream sediments so the limits established for arsenic in the regulations of Canada (33 ppm) and Holland $(55 \mathrm{ppm})$ have been considered here. The background level for an element, obtained from classic statistical techniques, is the mean value plus the coefficient of variation for the normal population and should represent the upper limit for a value that is certainly not anomalous. Thus a comparison of this value with risk parameters should give an idea of the environmental situation in a given area. The As background level of $68 \mathrm{ppm}$ (Table 2) in the near-shore samples (third or outer ring) is higher than the Canadian and Dutch limits. However, far higher As concentrations have been detected locally, for instance 129 and $192 \mathrm{ppm}$ in the Norizzi basin (Fiori et al. 2001), and these can be regarded to be at risk. Fig. 6 shows As distribution maps constructed using the statistical parameters given in Table 2. The peculiar characteristics of arsenic concentrations are clearly observed. Its highest values, along with the major anomalies, occur in the outer sampling ring which comprises both the stream inlets and sulphide occurrences fairly near to the edge of the lake at its maximum level. The maps also clearly show that, regarding bottom area and middle lake sampling, large portions of the lake yielded As contents consistently lower than the risk level. Arsenic minerals in the mineralisations and disseminations are represented by mixed sulphides where the pyrite-arsenopyrite association is frequently observed. These may be considered to be the chief As-carrier minerals in the source rocks while the nature of the As carrier phases in the derived residual soils and stream sediments is under study. When subjected to weathering these sulphides can release soluble arsenic into natural waters where arsenic forms no single cations but reacts readily to inorganic acids. During transportation the dissolved predominant arsenic species are in the higher $(+\mathrm{ve})$ oxidation states and are very effectively adsorbed onto ferric oxide-hydroxide goethite, manganese oxides, or hydroxides as well as onto clay minerals and organic matter. Its behaviour appears to be mainly controlled by these sorption processes even if a slow release may be possible and can be related to a $\mathrm{pH}$ increase in the aqueous phase.

It is quite likely that at least a part of the original readily weatherable sulphides still persist in the stream sediments. The grains deposited in proximal sediments may undergo oxidation during the dry season; floodwaters carry away the rest of the sulphide grains along with As oxyanions which in turn are adsorbed or co-precipitated onto $\mathrm{Fe}$ hydroxide as the $\mathrm{pH}$ reaches a sufficiently high value settling in the inner sediments. Furthermore, during recurrent drought, when precipitation is not sufficient to completely fill the lake and it is almost empty due to water deliveries, most of the bottom sediments undergo alternate phases of dryness and are reworked by the incipient river flows after the first heavy rains. The supply of new materials includes anthropogenic organic matter contained in the largely 

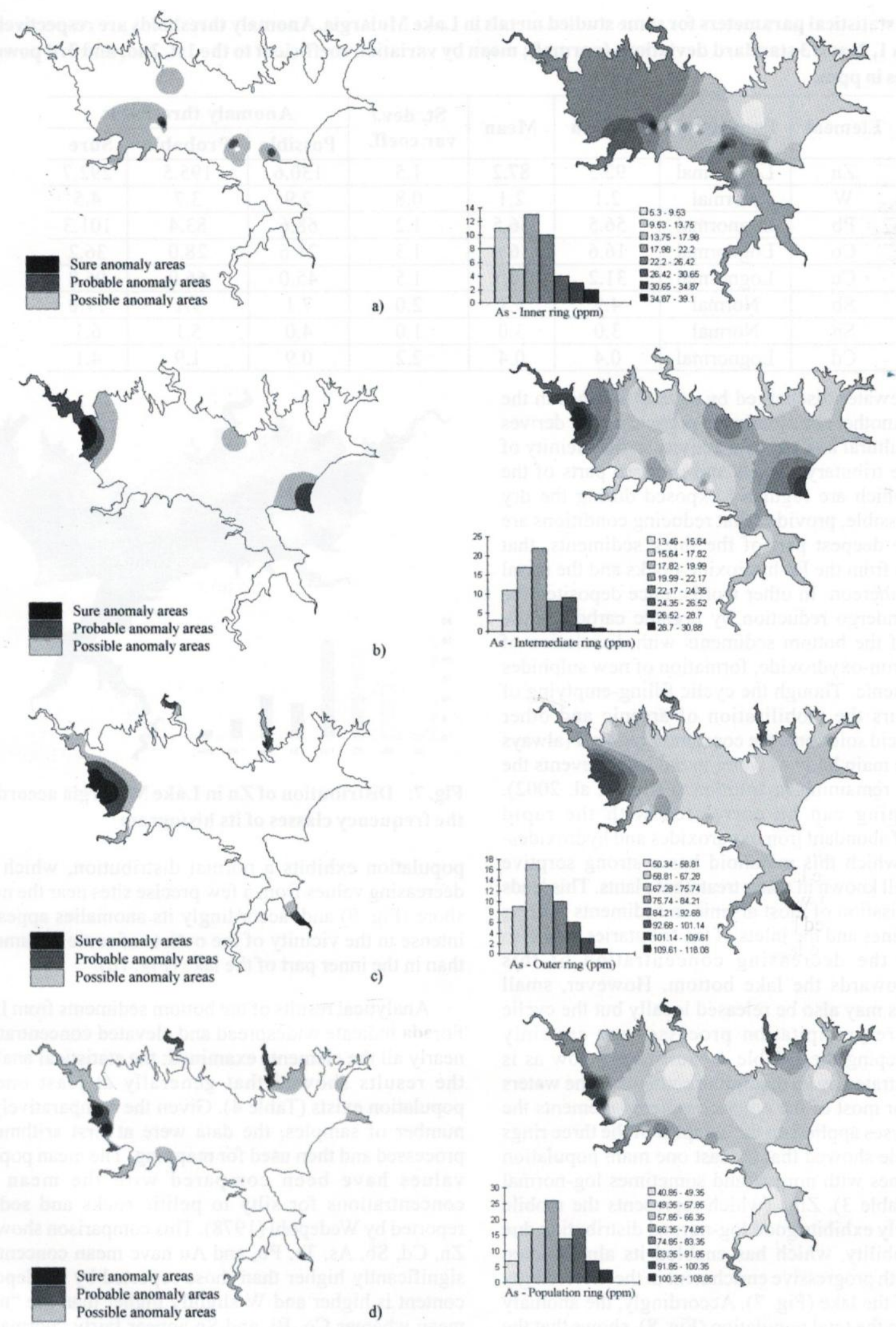

Fig. 6: The distribution of As in Lake Mulargia (left) according to the anomaly thresholds given in Table 2; the distribution of As according to the frequency classes (right) of their histograms relative to the three samples collected ( $\mathrm{a}$ - inner ring; b - intermediate ring; $\mathrm{c}$ - outer ring; $d$ - total population) 
Table 3: Main statistical parameters for some studied metals in Lake Mulargia. Anomaly thresholds are respectively given by: means plus 1,2, and 3 standard deviations (normal); mean by variation coefficient to the 1st, 2 nd, and 3 rd power (lognormal). Values in ppm.

\begin{tabular}{c|c|c|c|c|c|c|c}
\hline \multirow{2}{*}{ Element } & \multirow{2}{*}{ Population } & \multirow{2}{*}{ Median } & \multirow{2}{*}{ Mean } & \multirow{2}{*}{$\begin{array}{c}\text { St. dev./ } \\
\text { var.coeff. }\end{array}$} & \multicolumn{3}{|c}{ Anomaly thresholds } \\
\cline { 6 - 8 } & & & & Possible & Probable & Sure \\
\hline $\mathrm{Zn}$ & Lognormal & 92.5 & 87.2 & 1.5 & 130.6 & 195.5 & 292.7 \\
\hline $\mathrm{W}$ & Normal & 2.1 & 2.1 & 0.8 & 2.9 & 3.7 & 4.5 \\
\hline $\mathrm{Pb}$ & Lognormal & 56.5 & 56.5 & 1.2 & 68.6 & 83.4 & 101.3 \\
\hline $\mathrm{Co}$ & Lognormal & 16.6 & 16.6 & 1.3 & 21.6 & 28.0 & 36.2 \\
\hline $\mathrm{Cu}$ & Lognormal & 31.2 & 30.7 & 1.5 & 45.0 & 66.0 & 96.8 \\
\hline $\mathrm{Sb}$ & Normal & 4.9 & 5.1 & 2.0 & 7.1 & 9.1 & 11.0 \\
\hline $\mathrm{Sn}$ & Normal & 3.0 & 3.0 & 1.0 & 4.0 & 5.1 & 6.1 \\
\hline $\mathrm{Cd}$ & Lognormal & 0.4 & 0.4 & 2.2 & 0.9 & 1.9 & 4.1 \\
\hline
\end{tabular}

domestic wastewater discharged by several villages in the main valleys. Another contribution to organic matter derives from the agricultural and pastoral activity in the vicinity of the lake, in the tributary valleys and in those parts of the lake bottom which are regularly exposed during the dry season. It is possible, provided that reducing conditions are attained in the deepest part of the thick sediments, that sulphides form from the Fe-hydroxide flocks and the metal ions adsorbed thereon. In other words, once deposited the arsenic may undergo reduction by organic carbon in the deeper parts of the bottom sediments with dissolution of arseniferrous iron-oxydroxide, formation of new sulphides and soluble arsenic. Though the cyclic filling-emptying of the lake favours the mobilisation of arsenic and other elements into acid solutions, the constantly high $\mathrm{pH}$ (always above 8) of the main body of water in the lake prevents the elements from remaining in solution (Fadda et al. 2002). Arsenic trapping can be correlated with the rapid precipitation of abundant iron oxydroxides and hydroxidessulphates for which this metalloid has a strong sorptive affinity as is well known in water treatment plants. This leads to the immobilisation of most arsenic in sediments settling near the shorelines and the inlets of the tributaries as is also indicated by the decreasing concentration of this contaminant towards the lake bottom. However, small quantities of As may also be released locally but the cyclic mobilisation-re-precipitation processes are certainly effective in keeping the soluble As sufficiently low as is clearly demonstrated by its negligible contents in the waters of this lake. For most of the other considered elements the statistical analyses applied on the samples of the three rings taken as a whole showed that at least one main population exists, sometimes with normal and sometimes log-normal distribution (Table 3). Zinc (which represents the mobile elements) clearly exhibits good log-normal distribution due to its high mobility, which has enabled its almost even distribution, with progressive enrichment in the increasingly deeper parts of the lake (Fig. 7). Accordingly, the anomaly map, referred to the total population (Fig. 8), shows that the anomalies appear to occur well away from the main streams, in front of the Lake Flumendosa tunnel outlet and in the vicinity of the dam. For the metals related with clastic processes, W behaves in a different manner; its total

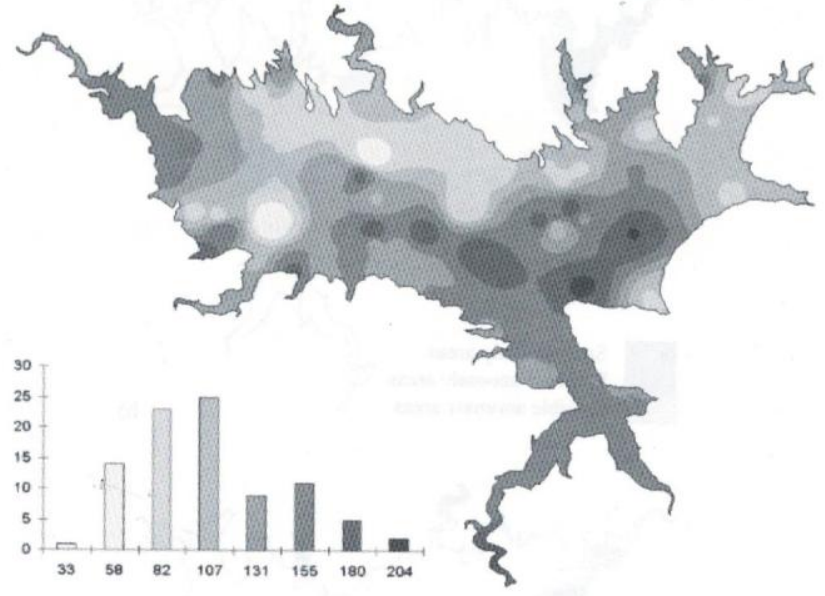

Fig. 7: Distribution of $\mathrm{Zn}$ in Lake Mulargia according to the frequency classes of its histogram

population exhibits a normal distribution, which shows decreasing values from a few precise sites near the northern shore (Fig. 9) and, accordingly its anomalies appear more intense in the vicinity of the outlets of some streams rather than in the inner part of the lake (Fig. 10).

Analytical results of the bottom sediments from Lake Sa Forada indicate widespread and elevated concentrations of nearly all the elements examined; the statistical analysis of the results showed that generally at least one main population exists (Table 4). Given the comparatively small number of samples, the data were at first arithmetically processed and then used for mapping. The mean population values have been compared with the mean world concentrations for silty to pelitic rocks and sediments reported by Wedepohl (1978). This comparison showed that $\mathrm{Zn}, \mathrm{Cd}, \mathrm{Sb}, \mathrm{As}, \mathrm{Te}, \mathrm{Pb}$, and $\mathrm{Au}$ have mean concentrations significantly higher than those reported by Wedepohl, $\mathrm{Cu}$ content is higher and W slightly higher than the "normal" mean whereas $\mathrm{Co}, \mathrm{Bi}$, and $\mathrm{Sn}$ appear fairly "normal". The anomaly maps of some elements (Fig. 11) show that, despite the small number of samples examined, a correlation does exist between the sources of mineral supply and the relative samples of stream sediments. All the examined metals display 


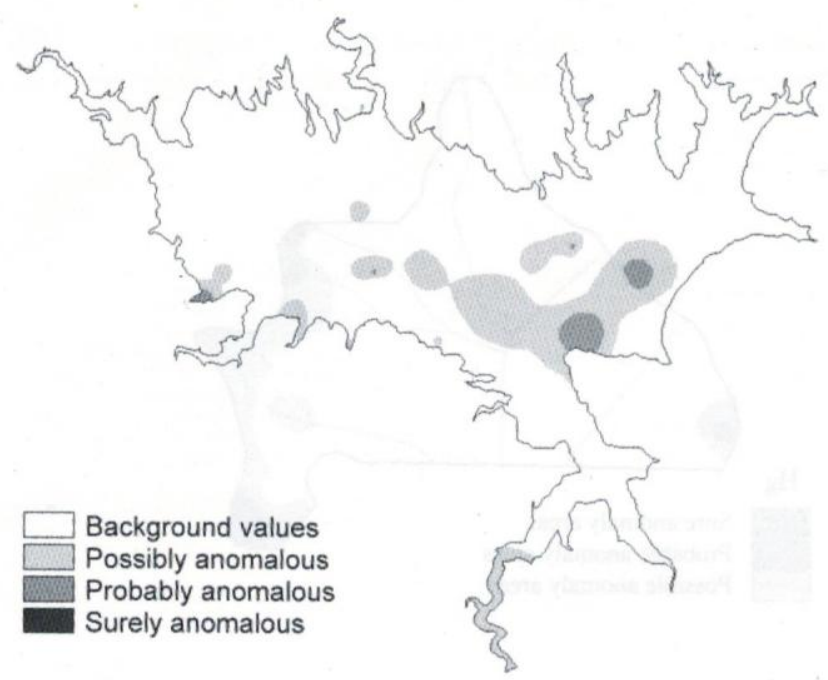

Fig. 8: Distribution of $\mathrm{Zn}$ in Lake Mulargia according to the anomaly thresholds referred to total population

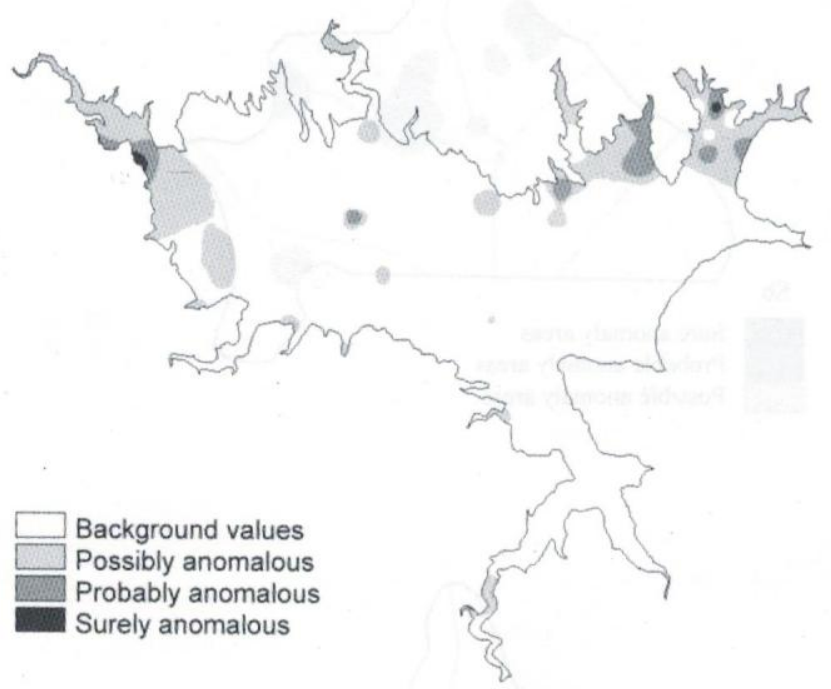

Fig. 10: Distribution of W in Lake Mulargia according to the anomaly thresholds referred to total population

regular distributions with unimodal histograms and a few clearly anomalous values. On the other hand, for most of these elements mean concentrations are significantly higher than those reported for similar sediments in other parts of the world, or are comparable with the highest known values. These observations are consistent with the small size of the drainage basin, its lithological homogeneity, and the abundance of several ore minerals. The mode of transport of these metals is governed by their physico-chemical properties. Gold, a typical "clastic" element, reaches the basin mostly after acid leaching of the sulphides. Tellurium in the paragenesis of metallic ore bodies occurs as tellurides, Terich tetrahedrite and in the native form. For a high oxidising potential these stable mineral phases tend to release Te, especially in arid climates, in highly oxidising and acid

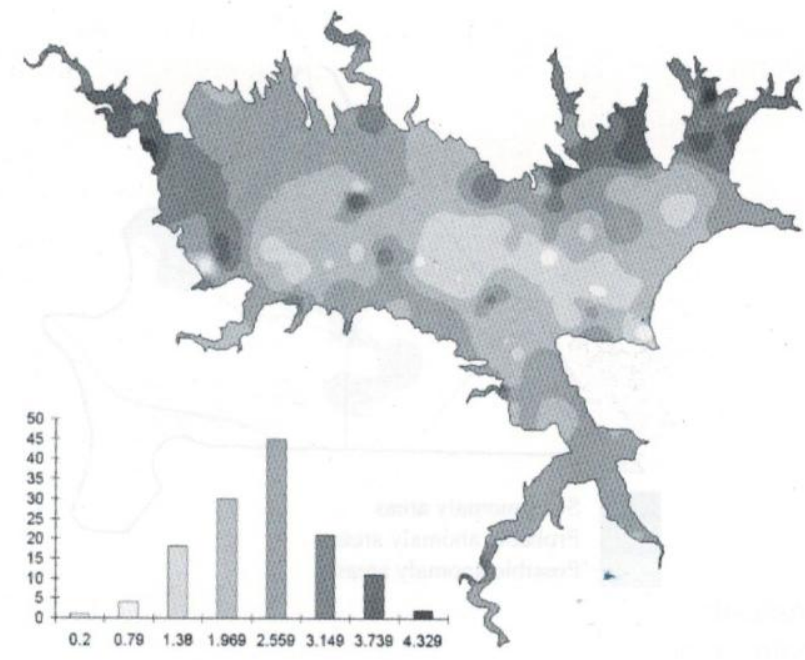

Fig. 9: Distribution of W in Lake Mulargia according to the frequency classes of its histogram

Table 4: Main statistical parameters for the studied elements in Lake Sa Forada. Anomaly thresholds are given for a normal population by: means plus 1,2 , and 3 standard deviations. Values in ppm.

\begin{tabular}{l|l|l|l|l|l}
\hline Element & Mean & $\begin{array}{l}\text { Standard } \\
\text { deviation }\end{array}$ & possible & $\begin{array}{l}\text { Anomaly } \\
\text { probable }\end{array}$ & $\begin{array}{c}\text { Threshold } \\
\text { sure }\end{array}$ \\
\hline $\mathrm{Zn}$ & 199.22 & 54.52 & 253.74 & 308.26 & 362.78 \\
\hline $\mathrm{Hg}$ & 0.19 & 0.09 & 0.28 & 0.37 & 0.46 \\
$\mathrm{Cu}$ & 46.93 & 11.1 & 58.03 & 69.13 & 80.23 \\
\hline $\mathrm{As}$ & 25.84 & 9.24 & 35.08 & 44.32 & 53.56 \\
$\mathrm{Sb}$ & 3.99 & 1.18 & 5.17 & 6.35 & 7.53 \\
$\mathrm{Te}$ & 0.25 & 0.09 & 0.34 & 0.43 & 0.52 \\
$\mathrm{~Pb}$ & 52.54 & 17.12 & 69.66 & 86.78 & 103.9 \\
$\mathrm{Au}$ & 0.024 & 0.012 & 0.036 & 0.048 & 0.060 \\
\hline
\end{tabular}

leaching environments (Wedepohl 1978). Hence, in the basin concerned, tellurium and its mineral phases may have travelled in the form of both clasts and ions. Tin does not occur in the paragenesis in its most common form of cassiterite but as stannite which was detected by means of electron microprobe. The presence of tungsten is more complicated in that no mineral phases containing this element have been recognised among the mineral paragenesis.

As far as arsenic is concerned, the main As-carrier are sulphosalts and the strongest anomalies have been observed at the lake edge. This finding is consistent with the sudden precipitation of the ions due to adsorption by the clay fractions and iron oxides and hydroxides and rapid settlement of the clasts. The fact that the highest concentrations of As, $\mathrm{Te}, \mathrm{Sb}$, and $\mathrm{Hg}$ contained in enargite and tennantite mineralogical phases were found in the eastern portion of the lake, strongly suggests that the minerals reach the basin in the form of clasts. The high content of mobile elements in the analysed material can be explained, at least for $\mathrm{Cd}$ and $\mathrm{Pb}$, by the fact that their ability to be adsorbed onto colloidal particles increases with $\mathrm{pH}$. The same considerations hold 
Fadda et al.
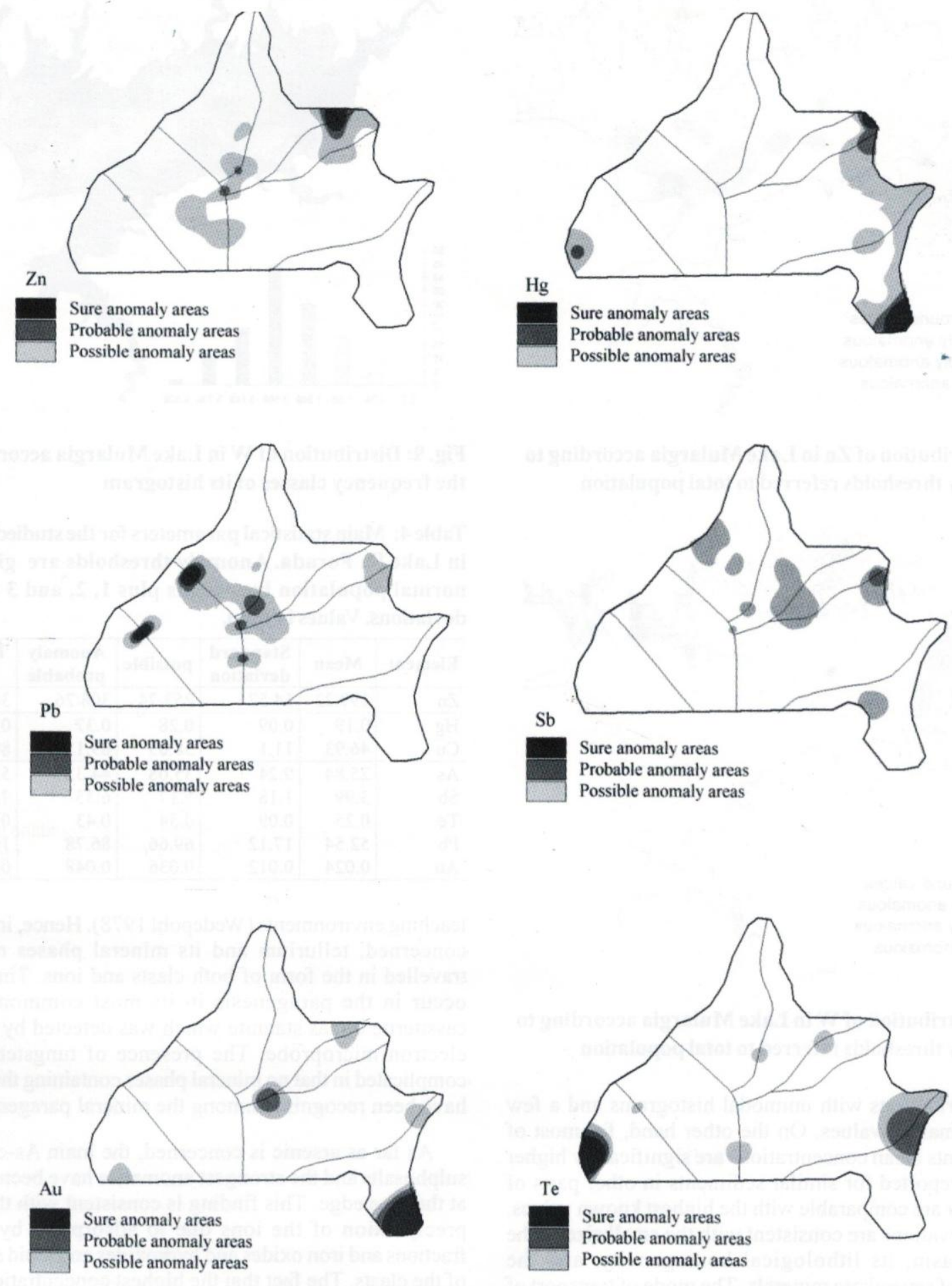

Fig. 11: Distribution of some elements in Lake Sa Forada according to the anomaly thresholds given in Table 4 
for $\mathrm{Zn}$ which is readily mobilised and has been observed to accumulate in the innermost parts of the basin.

Given a small size of the basin and the semiarid climate it can be reasonably assumed that the leaching solutions are strongly acidic, though only minor amounts are involved. On the other hand, the Sa Forada reservoir continuously receives waters from the much larger lakes of the Flumendosa system, characterised by a far higher (about 8) $\mathrm{pH}$ values (Fadda et al. 1996). Thus the seasonal acidic waters carrying metallic ions blend with the slightly alkaline lake water. The resulting increase in $\mathrm{pH}$ leads to a much greater amount of soluble elements being bound on the colloidal particles and on the clay fraction and Fe-hydroxides. Moreover the anomalous values are generally spatially related to the metal sources. The above findings suggest that the lake sediments act as a trap both for mineral clasts and metallic ions.

\section{CONCLUSIONS}

The main basins of the Flumendosa-Campidano reservoir system in Southern Sardinia are situated in orerich terrains. The ore occurrences and the contaminated soils are responsible for the supply of different heavy metals in the bottom sediments forming in these lakes.

Distribution maps were drawn in order to visualise dispersion and accumulation effects. They give an accurate description of the reservoirs and establish a clear reference picture of the hydraulic system before any future interventions on pollutant sources. The identification in the lakes of the true anomalies of elements departing from the background variations are as expected from the lithology of the watershed as well as the situation due to anthropogenic input. It is evident that the lake sediments have received large amounts of trace metals which are still being supplied. Since our data are based on a large number of measurements, we are quite confident that we have drawn a reliable picture of the elemental status of the lakes which not only provides a good estimate for both erosion and accumulation areas but also may be used to obtain a better knowledge of the mineralogical phases hosting the geochemical signals carried by the sediments. The rather high metal contents in the lake sediments appear to be a matter of concern, especially if solutions continue to derive from the readily weatherable minerals such as sulphides and the water coming from this lake system is used for drinking purposes. A significant upwards post-depositional leaching of the metals from the sediments by overlying waters is most likely when, immediately after emersion, sediment imbibition water oxidises sulphide to sulphate, and an acid $\mathrm{pH}$ is established; in these conditions, a good deal of metals can be mobilised and carried away by the water squeezed by sediment compaction; however a sudden increase of $\mathrm{pH}$ is able to precipitate a ferric hydroxide gel, which in turn is able to capture ions in a large quantity, as well as to re-precipitate metals in less soluble forms giving rise to an important downward diffusive flux from the overlying acidified water (mobilisation or desorption) to some subsurface sedimentary sink (adsorption-precipitation) located below the sedimentwater interface where metals would be effectively retained by the sediments. Precipitation of Fe-hydroxides, by mixing of squeezed acidic water with higher-pH river water, has been repeatedly observed in the field. At present the metalrich sediments of the lakes appear sufficiently stable as their concentrations in the water reaching the treatment plants are normally below the permissible limits for domestic use. Pollution risks connected with such a situation mostly depend on physico-chemical variations experienced by the periodically emerged and submerged sediments. Acid leaching would be the main dissolving factor, but conversely, a following $\mathrm{pH}$ increase would favour precipitation and accumulation in the deepest parts of the sedimentary piles which would act as a trap for the metals. Apart from the obvious dilution effect, the cyclic mobilisation-reprecipitation processes suggested by the present study are certainly effective in keeping the soluble metal contents in the waters of these lakes sufficiently low.

\section{ACKNOWLEDGMENTS}

The research was supported by the CNR, Istituto di Geologia Ambientale e Geoingegneria, and by University of Cagliari, Dipartimento di Geoingegneria e Tecnologie Ambientali.

\section{REFERENCES}

Bazzoffi, P., 1993, Analisi sulle cause dell'eutrofizzazione delle acque del sistema idraulico Flumendosa-Campidano in relazione all'applicazione della direttiva CEE sulle acque potabili. Inquadramento territoriale. Indagine sull'interramento dei laghi Flumendosa-Mulargia, v. 5, pp.1-39

Carmignani, L., Cocozza, T., Ghezzo, C., Pertusati, P. C., and Ricci C. A., 1982, Lineamenti del basamento Sardo. Guida alla Geologia del Paleozoico Sardo". Soc. Geol. It., pp. 11-23

Fadda, S., Fiori, M., Grillo, S. M., Marcello, A., Matzuzzi , C., and Pretti, S., 1996, Influenza della vecchia attività mineraria nel bacino del Lago Flumendosa e sui contenuti di metallo nei sedimenti del Lago Mulargia. Atti del Congresso Internazionale per il Centenario dell'Associazione Mineraria Sarda, pp. 137-149

Fadda, S., Fiori M., Grillo S. M., Marcello A., and Pretti S., 1998, Distribuzione di metalli pesanti nei sedimenti di alcuni laghi artificiali della Sardegna. GEAM, v. 93, pp. 55-60

Fadda, S., Fiori, M., Grillo, S. M., Matzuzzi C., and Valera, P., 2002, Arsenic contamination of natural origin in stream sediments of Lake Mulargia Reservoir, Southern Sardinia. Proc. Intern Conf. Uranium Mining and Hydrogeology III and the Intern. Mine Water Association Symposium, pp. 1037-1045

Fiori, M., Grillo, S. M., Marcello, A., Pinna, D., and Pretti, S., 2001, Heavy metal pollution of natural origin in the Rio Norizzi basin (SW Sardinia, Italy). The As aspect. Proceedings of the Tenth International Symposium on Water-Rock Interaction, pp. 1091-1094

Istituto dell'Ambiente di Ispra, 1992, Sistema idraulico Flumendosa-Campidano: "Indagine conoscitiva sui sedimenti". Centro Comune di Ricerca, pp. 1-330 
Marcello, A., 1961, Il bacino Permico del Rio Mulargia (Medio Flumendosa) e le sue successive modificazioni geologiche. Phth, pp. $1-39$

Pinna, D., 2000, I metalli pesanti nei sedimenti fluviali del bacino imbrifero ed in quelli lacustri del Lago del Medio Flumendosa: distribuzione e rischio di rilascio. $\mathrm{Ph}$. D.
Stumm, W. and Morgan, J., 1970, Aquatic Chemistry. An Introduction Emphasizing Chemical Equilibria in Natural Waters. Willey \& Sons, Inc. New York, 583 p.

Wedepohl, H. K., 1978, Abundance in common sediments and sedimentary rocks. Wedepohl H. K. (ed.) Handbook of geochemistry, Springer 